\title{
Deducting Collateral Benefits From Damages: Principle And Policy
}

\author{
Richard Lewis *
}

Schemes for compensating injury which operate alongside each other call for important policy decisions to be made concerning their inter-relationship. Are they to take account of one another and, if so, to what extent? These issues can arise in a variety of contexts. Within particular regimes they are the concern, for example, of the overlapping benefit regulations in social security law and the rules relating to contribution in insurance law. However, the focus of this article is upon personal injury litigation. It examines the policy reasons which have been used to justify the different results reached by the law when faced with the problem of "collateral benefits" received by an accident victim also seeking damages. Typically these benefits are received from the state, or an employer, or an insurer. Two major questions then arise: should they be taken into account to reduce the damages payable by the tortfeasor; and should those who provide the additional source of compensation be able to obtain reimbursement of the monies they have paid out?

The area has recently been investigated by the Law Commission as part of its programme reviewing the law of damages for personal injury. The policy analysis presented in this article is somewhat broader than that discussed in the Commission's Consultation Paper issued in September 1997. ${ }^{1}$ Although this article does not set out to examine the individual proposals for reform suggested by the Commission, it does provide an additional perspective from which they may be evaluated. It identifies certain common themes in the policy arguments even though the particular collateral benefits involved may be quite different in source, aim and

\footnotetext{
* Professor, Cardiff Law School, University of Wales.

${ }^{1}$ Damages For Personal Injury: Collateral Benefits (1997) Consultation Paper No 147. The associated area of recoupment of NHS costs from tortfeasors was considered in the earlier paper Damages For Personal Injury: Medical Nursing And Other Expenses (1997) Consultation Paper No 144. For examination of the substantive rules in a specific context see Lewis, "The Overlap Between Damages For Personal Injury And Work Related Benefits" (1998) 27 ILJ (forthcoming).
} 
character. Although subject to many qualifications, these recurring arguments are organised here into a framework which can be used to evaluate new cases and reconsider the policy issues.

The subject is therefore topical. It also constitutes a neglected and yet important area of compensation law. Before the Law Commission review comparatively little had been written on collateral benefits in spite of the fact that it is difficult to overestimate the importance of coordinating the plethora of compensation schemes for those injured. ${ }^{2}$ Over fifty forms of financial assistance for disablement have been traced. ${ }^{3}$ The series of ad-hoc schemes exposes the lack of any coherent policy towards the treatment of disabled people. Some receive much more help than others even though their needs and injuries are the same. It is not only the particular conditions of entitlement which cause the inequalities of treatment, but also the differing provisions with regard to the receipt of collateral benefits. The fortunate few who are able to obtain compensation from the common law are especially well treated. Because of their collateral benefits some plaintiffs recover far more than their pecuniary loss. ${ }^{4}$ This waste involved in paying what may amount to double

\footnotetext{
${ }^{2}$ Academic writing upon the law of tort is overwhelmingly biased towards the issue of liability rather than quantum, an emphasis which does not reflected the importance of assessment of damages to practitioners and litigants. However, the collateral source problem is considered in a handful of U.K. articles, almost all critical of the waste resulting from failures to deduct from damages. See Ganz, "Mitigation Of Damages By Benefits Received" (1962) 25 MLR 559, McGregor, "Compensation Versus Punishment In Damages Awards" (1965) 28 MLR 629, Atiyah, Collateral Benefits Again" (1969) 32 MLR 397, Casey, "Damages And Social Security Benefits" [1972] Juridical Rev 22, Williams, "State-Financed Benefits In Personal Injury Cases" (1974) 37 MLR 281, Davies, "State Benefits And Accident Compensation" (1982) J Soc Welfare L 152. The most significant contribution is that of J. G. Fleming "The Collateral Source Rule And Loss Allocation In Tort" (1966) 54 Cal L Rev 1478, and "Collateral Benefits" in International Encyclopedia Of Comparative Law (Vol. XI) chap 11. Textbook writers also devote little attention to the rule. But see A. Ogus, The Law Of Damages (1973) p 218 - 230, P. Cane, Atiyah's Accidents Compensation And The Law (5th ed 1993) chap 15, and A. Burrows, Remedies For Torts And Breach Of Contract (2nd ed 1994) p $121-135$.
}

${ }^{3}$ Consumers Association, Managing At Home - A Which Campaign Report (1978) and J. Simkins and V. Tickner (eds), Whose Benefit? An Examination Of The Existing System Of Cash Benefits And Related Provision For Intrinsically Handicapped Adults And Their Families (1978).

${ }^{4}$ In the U.S.A. it was found that the average plaintiff injured in a road accident received $\$ 1.40$ for each $\$ 1$ of pecuniary loss. This was partly because $79 \%$ of plaintiffs had at least one collateral source of payment in addition to damages. See the All Industry Research Advisory Committee, Automobile Injuries And Their Compensation In the United States (1979). Of those traffic victims in the USA who are successful in tort claims it has been suggested that two thirds of their total recovery comes from sources other than the tortfeasor. See J. O'Connell, The Injury Industry (1971) chap 4 p 29. This was confirmed in an empirical study by D.R. Hensler et al, Compensation For Accidental Injuries In The United States (1991). 
compensation is a feature of tort law which has been highlighted by Atiyah. ${ }^{5}$ Although his general views on reform of the law are not shared by the present Law Commission, it now recognises

" ... the force of the contention that the damages burden should be reduced by the amount of collateral benefits so that money could thereby be released to contributors to liability insurance through lower premiums, which would in turn potentially increase the funds available to achieve better provision for all the ill and injured."6

The questions posed by collateral benefits therefore lie at the heart of any compensation system, and constitute the key to its future direction.

\section{POTENTIAL SOLUTIONS TO THE POLICY QUESTIONS}

In summary, there are three potential solutions to the problems posed by collateral benefits:

\section{(i) Cumulation}

Here the damages take no account of the other sources of compensation. The plaintiff receives damages in full, irrespective of the extent to which his losses may already have been made good by other sources. For plaintiffs this is the most favourable of the three solutions because it enables them to receive multiple compensation without being required to repay the sources of their collateral benefits. The result is sometimes called an application of the "collateral source" rule. ${ }^{7}$ At first sight the plaintiff appears to be overcompensated and this wasteful solution seems to have little to commend it. However, arguments can be made to support the rule especially where damages alone are seen as inadequate compensation, or where the plaintiff has paid for the collateral benefits and is thought to have a right to the extra money.

\footnotetext{
${ }^{5}$ P. Cane, Atiyah's Accidents Compensation And The Law (5th ed 1993) pp 322 - 330.

${ }^{6}$ Op cit n 1 para 4.25.

${ }^{7}$ In the USA the rule has been defined by the 2 nd Restatement of Torts (1977) s. 920 A(2) as: "Payments made to or benefits conferred on the injured party from other sources are not credited against the tortfeasor's liability, although they cover all or a part of the harm for which the tortfeasor is liable."
} 


\section{(ii) Recoupment}

By contrast this solution arranges for the collateral source to be reimbursed and thus prevents the plaintiff from being overcompensated. It also ensures that the wrongdoer does not benefit from the payments made by the collateral source. Although these payments may help to meet the plaintiff's immediate needs, ultimately they must be refunded by the tortfeasor. If the administrative cost of repaying the benefits is not excessive, this solution on the surface appears the most attractive.

\section{(iii) Reduction}

Here the damages are reduced by the amount of benefit received, but the collateral source is given no right to seek reimbursement. This produces the most favourable result for defendants because not only do they pay less money to plaintiffs, but they also have no duty to refund the payments from the collateral sources. Although this simple rule can be criticised as providing a subsidy to tortfeasors, it avoids the wasteful litigation and administrative cost sometimes associated with recoupment.

\section{THE USE OF PRINCIPLE}

Judges have often been uncertain which of these three policy solutions to adopt and yet have been reluctant to discuss them in detail. Instead they have frequently merely reformulated the problem of whether or not to deduct benefit by using the language of causation, or focusing upon the meaning of the word "collateral," or simply by asking what is fair, just and reasonable. They have preferred to apply principle rather than policy. That is, they have preferred the formal language of legal rules and concepts to discussion of more pragmatic considerations. This has hindered rational discussion of the subject. 


\section{(i) Meaning Of Collateral}

Little can be solved by simply asking "is this benefit collateral or not?" ${ }^{8}$ The benefit will be called collateral if it is to be deducted, but it will not be if it is to be left out of account. ${ }^{9}$ There is no inherent meaning in the word which can be used as a litmus paper test to solve the problem. Nor are the difficulties avoided by translating the question into Latin and asking whether the benefit is a res inter alios acta for the same objections then apply.

\section{(ii) Just, Fair And Reasonable}

Similarly, the simple assertion by a judge that the result is fair or just is of little value. An illustration of this approach is to be found in Browning $v$ War Office ${ }^{10}$ where Lord Denning suggested that although it could be difficult "to say when it is or is not fair and just to take the receipts into account" it would "obviously" not be fair in particular cases. ${ }^{11}$

\section{(iii) Cause In Law}

Causal language alone cannot determine whether there is a sufficient relationship between the injury and the receipt of compensation for deduction to be made. To ask whether the accident is the "direct", "effective" or "proximate" cause of the plaintiff receiving the non-tort monies (therefore making them deductible) does not help if we accept these words are so variable in meaning as to be worthless. Again matters are not improved if the question is translated into Latin and we ask whether the accident is the causa causans of the additional payments. ${ }^{12}$

${ }^{8}$ The test is easier to formulate than to apply according to in Asquith LJ in Shearman v Folland [1950] $1 \mathrm{~KB} 43$.

${ }^{9}$ There is potential for confusion here because the word collateral is often used to mean compensation from an additional source whether or not it is to be deducted.

${ }^{10}$ [1963] 1 QB 750 at p 759.

${ }^{11}$ The limited value of such an approach was acknowledged by Lord Bridge in Hussain $v$ New Taplow Paper Mills [1988] 1 AC 514 at p 528.

${ }^{12}$ Similarly see the criticism of Payne $v$ Railway Executive [1952] 1 KB 26, Judd $v$ Hammersmith Hospitals [1960] 1 All ER 607 in (1960) 76 LQR 347, and Sir Owen Dixon in The National Insurance Co of New Zealand $v$ Espagne (1961) 105 CLR 569 at p 572 followed by the several pages of trenchant criticism of causation given by Windeyer $\mathrm{J}$ at $\mathrm{p} 590$ et seq. 
Nevertheless it has been common for judges to use causation to justify their decisions on collateral benefit. For example, in the leading case dealing with the non-deductibility of payments from a charitable fund it was argued that it was not the tort which had caused the payments to be made; instead they derived only from the generosity of the contributors. ${ }^{13}$ Again in the leading case dealing with insurance receipts it was argued that the plaintiff "does not receive [his insurance money] because of the accident, but because he had made a contract providing for that contingency." 14 Of course, the insurance payments were in fact made because of the accident in the sense that if it had not occurred they would not have been made. But that is not what the judge meant by his causal language. He was asserting that, although the accident caused the payment in fact, it ought not to be considered the cause of the payment in law. However, that is the statement of a conclusion rather than a rational argument made in support of it. The decision cannot be justified by the use of causal language alone.

Judges have become more critical of the assertions rooted in such language, and have gradually abandoned the cause in law argument. For example, in Parry $v$ Cleaver four of the five members of the House of Lords clearly rejected the use of causation as a means for solving the problem. The one exception was Lord Pearson, but even he made no mention of causation when he later chaired the Royal Commission on Civil Liability. ${ }^{15}$ In spite of these criticisms causation is still occasionally employed to help determine collateral benefit cases. ${ }^{16}$

\section{(iv) Cause In Fact}

Unlike cause in law, cause in fact can be relevant in deciding whether or not to deduct the benefit from tort damages. For a deduction to be made it is essential,

\footnotetext{
${ }^{13}$ Redpath v Belfast and County Down Railway (1947) NI 167 at p 172.

${ }^{14}$ Bradburn v Great Western Railway Co (1874) LR 10 Exch 1.

${ }^{15}$ Report Of The Royal Commission On Civil Liability And Compensation For Personal Injury (1978) cmnd 7054, vol 1 chap 13.

${ }^{16}$ For example, in Bews $v$ Scottish Hydro Electric [1992] SLT 749 at p 751 cumulation of benefit was allowed partly because it was held that it "was not his death which triggered the payment ... [but] the exercise of the defenders discretion to make it." In Longden v British Coal [1995] PIQR Q 48 Roch LJ considered an incapacity pension to result not from the accident but from the contributions paid by the accident victim.
} 
although not sufficient by itself, to show that the accident is the necessary cause of the payment of benefit. The key question is: "If there were no accident would the plaintiff still have received the benefit?" If so, the accident is not the cause in fact of the payment and it should be left out of account when damages are assessed. For example, in order to deduct a redundancy payment from damages it must be shown that it was the injury to the plaintiff, and not other factors, which caused him to be made redundant. ${ }^{17}$

Just as plaintiffs can only claim for harm caused by the accident, defendants cannot expect damages to be mitigated by factors unrelated to the accident. If the accident forces the plaintiff to draw upon his bank savings, the proceeds are not to be taken into account in assessing damages because he would have had access to this money even if there were no accident:

"... it is perfectly clear that he is not made whole until he again has that money to put in the bank for his children, or his old age, or even to squander, as he had planned."18

In this respect damages are assessed irrespective of the plaintiff's actual need for them so that, for example, no notice is taken of the fact that the accident victim is very rich and can easily pay for medical treatment. In this way the defendant must take the plaintiff as he finds him. Similarly, no account is taken of the fortunes of life which benefit the plaintiff after the accident occurred provided that the accident did not help to produce such good fortune. If, for example, the plaintiff wins the lottery the day after he suffers his accident, his windfall is not caused by the accident and will be irrelevant to the amount of damages he receives.

Cause in fact, therefore, is relevant in determining whether the necessary conditions are present for there to be further consideration of whether benefits should be deducted from tort damages. The outcome of that further debate will depend upon which of the policy solutions considered in the next section is preferred. The application of principle has been of little help.

\footnotetext{
${ }^{17}$ Mills v Hassall [1983] ICR 330 cf Wilson v National Coal Board [1981] SLT 67 and Colledge $v$ Bass Mitchells \& Butler [1988] 1 All ER 536.

${ }^{18}$ F. V. Harper and F. James, Law Of Torts Vol 2 (1956) p 1348.
} 


\section{REVIEW OF THE POLICY OF CUMULATION}

\section{Objections To Cumulation}

There are several obvious objections to allowing plaintiffs to receive damages in full irrespective of the extent to which losses may already have been made good by other sources. First, this cumulation seems contrary to certain basic tenets of the award of damages.

"The underlying principle is, of course, that damages are compensatory. They are not designed to put the [injured party] ... in a better financial position than that in which he would otherwise have been if the accident had not occurred." ${ }^{19}$

The often stated aim $^{20}$ of returning the plaintiff as far as possible to the position which he was in before the accident occurred suggests that all receipts resulting from the accident should be brought into account. Similarly, the principle that after the accident the plaintiff should be required to mitigate his loss seems to require notice to be taken of other sources of help available to him. Cumulation allows overcompensation to occur and this is contrary to these principles of the law of damages and the rationale of economic efficiency which lies behind them. Cumulation has instead been associated with a desire to ensure that wrongdoers pay in full for injuries they cause, and this philosophy of punishment is incompatible with tort's aim of paying no more than full compensation.

A second objection is that cumulation allows some accident victims to be treated very generously compared to others, a disparity which is made more acute if social security provision for disabled people is considered meagre. It appears very unfair that the few accident victims able to succeed in tort should be able to claim so much more for the same losses. Finally, cumulation appears to result in the compensation system being more expensive than it need be. It is argued that the bill for the overall compensation system is ultimately borne by the public as a whole, ${ }^{21}$ and in order to

\footnotetext{
${ }^{19}$ Lord Oliver in Hodgson $v$ Trapp [1989] 3 All ER 807 at p 826, similarly Lord Bridge at p 819.

${ }^{20}$ Egs Lord Griffiths in Dews v National Coal Board [1988] AC 1 at p 12, and Lord Goddard in British Transport Commission v Gourley [1956] AC 185 at p 206.

${ }^{21}$ Eg P. Cane, Atiyah's Accidents Compensation And The Law (5th ed 1993) p 323: " ... in modern conditions, 'public money' is not just money which is actually collected by the State in the form of taxes or social security contributions. Tort damages too are, for all practical purposes, paid out of
} 
allocate as efficiently as possible the scarce resources available, care should be taken to ensure that the same item of loss is not compensated twice over.

Cumulation seems profligate and wasteful. As Atiyah argues:

"Public money should not be wasted by over-compensating some personal injury victims, particularly when so many other deserving cases ... receive much less ...."22

We now consider the arguments that may be used to counter these basic criticisms of the collateral source rule.

\section{(i) Is Cumulation Justified If The Plaintiff Has Paid For, Or Otherwise Earned, The Additional Payments?}

If the plaintiff has earned the extra money why should the defendant benefit? The argument in favour of cumulation is stronger if any of the following apply:-

$\rho \quad$ The plaintiff freely chose to buy the additional benefits from his own disposable income and was not required to do so by, for example, his employer or by the national insurance system.

$\rho \quad$ The plaintiff acted prudently and with foresight in purchasing the additional payments. $^{23}$

The denial of the additional payment robbed the plaintiff of all benefit from the contract he entered into in order to secure it. ${ }^{24}$

public money, since they are mostly financed by ... insurance premiums which are paid by a very large proportion of the public."

22 Ibid. Similarly D. Harris, Remedies In Contract And Tort (1988) p 295: "Double compensation from public sources is inefficient, and, when resources are limited, is unfair to the many accident victims whose only support is means-tested ...." S. Sugarman, Doing Away With Personal Injury Law (1989) p 174 recognises that the common law system operates on the principle that tort payments are "primary" and others "secondary," but that this results in wasteful duplication of payment. He supports abolition of the collateral source rule. "From the viewpoint of administrative efficiency, having tort law serve only in a backup (that is, secondary) role, paying for losses that are otherwise uncompensated, is far more sensible."

${ }^{23}$ If we deny him the extra monies we may discourage such prudence and, for example, reduce the incentive for buying first party insurance even though this distribution of risk is of benefit to the wider community. It also seems unfair that the prudent insured should receive the same total compensation as the spendthrift who has shown no concern about obtaining protection from the risk involved.

24 Thus Asquith LJ in Shearman v Folland [1950] 2 KB 43 at p 46 objected to deducting private insurance monies from damages: "If the wrongdoer were entitled to set off what the plaintiff was entitled to recoup or had recovered under his policy, he would in effect be depriving the plaintiff of all benefit from the premiums paid by the latter and appropriating that benefit to himself." In Parry $v$ Cleaver [1970] AC 1 Lord Reid similarly implied that the plaintiff would have wasted the money spent 

tort damages.

However, there are a number of difficulties with these arguments which diminish their persuasiveness. There are five major points to be made:-

\section{(a) The plaintiff may not have paid for the additional payments nor exercised foresight and prudence to obtain them}

Where the plaintiff purchases private insurance he may indeed be acting with foresight and care in arranging to pay the premiums from his disposable income. But often this picture of self-sufficiency, prudence and thrift is inaccurate. First, the premiums may be paid by someone other than the plaintiff (as where employers arrange medical or accident or disablement insurance). Secondly, the plaintiff may have had no choice but to become a beneficiary of the insurance policy. This may happen not only where the insurance benefit is part of the remuneration for a job, but also in other circumstances where in practice it is difficult to avoid becoming insured. ${ }^{25}$ Thirdly, the purchase of insurance does not necessarily indicate either thrift or foresight. On thrift the Law Commission note that the prudent course might be not to buy insurance if it does not represent value for money. ${ }^{26}$ As for foresight, it can be agreed that the motive for buying insurance may be to provide security in the event of an accident. But the reason for the purchase will rarely be to arrange for double recovery in the much less likely event of the injury being caused by a tort. ${ }^{27}$ In summary this means that the plaintiff may be unaware of the full extent of the insurance protection from which he benefits, and his privileged position may not result from his own prudent management of his affairs.

on paying premiums which had he not done so, would still have been "in his possession at the time of the accident grossed up at compound interest."

${ }^{25}$ For example, the plaintiff may be required to take out life insurance as a condition of his obtaining a mortgage, and accident insurance may be part of a package bought when taking a holiday or when arranging for the comprehensive insurance of a motor vehicle. Often plaintiffs are unaware of the extent that they are insured.

${ }^{26}$ Consultation Paper Collateral Benefits (1997) para 4.42.

${ }^{27}$ Fleming, "Collateral Benefits" in International Encyclopedia Of Comparative Law (Vol. XI) chap 1114. 
Where the benefit derives from work the plaintiff can argue that it has been paid for, at least indirectly, by his labour. In effect the cost of the insurances and benefits supplied by the employer is an addition to the plaintiff's salary, and can determine whether or not employment is accepted. ${ }^{28}$ However, if the plaintiff pays for the extra benefits in this indirect way, his argument for retaining them is weaker than where he buys the insurance himself. Where the additional benefit is provided by the state the plaintiff's argument becomes even more difficult to sustain. National insurance contributions nowadays are far more akin to levies of taxation than payments of private insurance premiums. Even forty years ago a Departmental Committee was able to reject the comparison between the contributions for private insurance on the one hand and public insurance on the other. ${ }^{29}$ This was because national insurance contributions are compulsory and not the result of individual thrift; the insured is not responsible for paying all the premiums because the employer is also required to make a contribution; and finally, the National Insurance fund which results is insufficiently separated from the pool into which general tax revenues are paid. ${ }^{30}$

Cumulation is easier to justify where the collateral benefits are not universal or obtained as a matter of routine. When the policy of cumulation was first adopted in the nineteenth century markets for first party personal injury insurance were only just developing, and other forms of collective protection were very limited. From the defendant's perspective it could not really be expected that the injured person would carry any protection. However, this has changed with the twentieth century development of both public and private forms of welfare. It has been suggested in the USA that the changes made to social insurance and employment benefits since only the 1950's justify abrogating the policy of cumulation. ${ }^{31}$ However, where this has led to the removal of the traditional collateral source rule an exception has often been made for life insurance. The reason for this is that

\footnotetext{
${ }^{28}$ Bushe emphasises the value of fringe benefits from the perspective of a labour economist in "A Single Guiding Rule For Damages Awards In The Presence Of Collateral Benefits" (1995) 25 HKLJ 51.

${ }^{29}$ Report Of The Departmental Committee On Alternative Remedies (1946) cmnd 6860, chaired by Sir Walter Monckton, para 32.

${ }^{30}$ A. Ogus et al, The Law Of Social Security (4th ed 1995) p 26 and 40.

${ }^{31}$ S. Sugarman, Doing Away With Personal Injury Law (1989) p 79.
} 
"... life insurance continues to be acquired in accordance with nineteenth-century norms. Many people purchase life insurance but others do not .... [T] he face amount varies dramatically from policy to policy, and remains a matter of individual choice. Furthermore, the cost

$\ldots$ is borne by the individual who purchases the policy." 32

In summary the strongest arguments for allowing multiple compensation occur where the collateral payments are uncommon, and derive from schemes to which the plaintiff makes a contribution from his own disposable income. However, even then there remain the criticisms of the collateral source rule considered in the next four headings.

(b) If the plaintiff has paid for the additional payments he does not pay for tort damages in the same sense

The argument that the plaintiff has paid a price for his additional payments can be countered by noting that a reduction is sought not in the monies from the collateral source, but in the damages awarded at common law. ${ }^{33}$ It is possible to reduce these damages because the right to them has not been bought in the same way as that to payment under an insurance policy. Plaintiffs do not pay directly for the monies they receive from the tort system - they do not pay premiums into an insurance fund in order to gain compensation. Instead they rely upon the defendant having the capacity to pay damages, and this usually means that they rely upon the defendant having paid liability insurance premiums. Although it can be argued that these costs are passed on and are borne indirectly by society as a whole, a plaintiff's entitlement to damages bears no relationship to the amount he may have contributed indirectly to fund the tort system. He will not therefore have paid for tort damages in the same sense as he may have paid for his insurance monies, and therefore it is easier to say that the damages should be reduced to ensure that the plaintiff is not overcompensated.

\footnotetext{
${ }^{32}$ Schwartz, "A National Health Care Program: What Its Effect Would Be On American Tort Law And Malpractice Law" (1994) 79 Cornell LR 1339 at p 1346. Similarly life insurance is exempt from the wide deduction principle proposed by the American Law Institute, Enterprise Responsibility For Personal Injury Vol 2 (1991) chap 6.

${ }^{33}$ Atyiah, "Collateral Benefits Again" (1969) 32 MLR 397, at p 403: "To argue that he has 'paid for' his insurance payments is beside the point when it is not the insurance payments which are in issue. It might be more pertinent to ask if he has 'paid' for his right to a tort action, to which of course there can only be one answer." Similarly, P. Cane, Atiyah's Accidents Compensation And The Law (5th ed 1993) p 324.
} 
(c) If the additional payments are deducted from damages the plaintiff is not robbed of all benefit from the contract giving rise to the payments

Plaintiffs do not take out first party insurance in order to give themselves extra protection against tortious injuries by supplementing the damages that they may gain from the common law. Instead they seek protection against all causes of injury, whether or not caused by negligence. This protection is far wider than that against tortious injuries alone because only a minority of accident victims are able to pursue a common law claim.

It is therefore wrong to suggest that if insurance proceeds are deducted from tort damages all the value of the insurance contract is thereby lost. Before the injury occurred the plaintiff had the benefit of wide coverage under the policy. If he had been unable to claim in tort he would have been able to rely upon his contractual rights to obtain compensation. To consider these rights as worthless only because the insurance payments are later set off against the damages award is to fail to appreciate why such contracts are taken out in the first place. The insurance covers the many accidents where no tort is involved. In addition, it provides benefits even to those who may be able to claim in tort:

“... [E]ven if the plaintiff's injury is caused tortiously the tortfeasor may be insolvent. Beyond this, the plaintiff may prefer to rest content with his insurance proceeds and avoid all the time, trouble and uncertainty which is necessarily involved in bringing a lawsuit. And even if he is prepared to go ahead with litigation, he may need money right away for medical and living expenses and find it hard to await upon an eventual judgment in his favour. In effect the person taking out accident insurance does so in order to secure himself against the financial consequences of an accident and not to indulge himself in the speculative gamble of double recovery where his injury is caused tortiously." 34

Another attack on the argument that the plaintiff's contract has been completely undermined is that it is circular. If the price paid by the plaintiff for the additional benefits reflects the ability of the provider to recoup the payments made, then there can be no objection.

\footnotetext{
${ }^{34}$ McGregor, "Compensation Versus Punishment In Damages Awards” (1965) 28 MLR 629 at p 636. Similarly see Fleming "The Collateral Source Rule And Loss Allocation In Tort" (1966) 54 Cal L Rev 1478 at p 1500, and the anonymous notes in (1949) 63 Harvard LR 330 at 332 and (1964) 77 Harvard LR 741 at $p 751$.
} 
"Insurance and employment benefit arrangements are contractual; the price to the beneficiary depends on the scope of benefits agreed upon. Should the insurer or employer acquire rights of reimbursement or subrogation, the cost of the arrangement to the beneficiary would go down. The legal result cannot properly be predicated on the consideration paid; rather it must be the other way around. ${ }^{35}$

(d) It is difficult to establish that the plaintiff had a reasonable expectation of receiving payments in addition to damages

To receive support, the plaintiff's expectation of receiving benefit must be reasonable. This is harder to establish if the plaintiff has not paid directly for the benefit, as may happen in the ways already described. The plaintiff's case will be stronger if he can establish that he has relied on the expectation of receiving more money. However, such reliance often cannot be established because the plaintiff before the accident was unaware of the source of additional payments which later became available to him. Where there is no reliance, the argument can be turned against the plaintiff. If he is deprived of the extra benefits it is sometimes claimed that he suffers only the loss of a windfall payment, akin to a successful gambling bet, rather than monies which are essential for his future maintenance and well being. There is much less reason to support the profits of a gamble ${ }^{36}$ than where the plaintiff has a true "insurable interest" where he will suffer a net financial loss unless payment in full is made. ${ }^{37}$ It can therefore be difficult to establish that the plaintiff had an expectation of receiving additional benefit which the law ought to support. In any event, the plaintiff's expectation is only one factor in determining whether multiple compensation should be allowed. It must be balanced against other policy considerations, and cannot alone justify the collateral source rule.

\footnotetext{
${ }^{35}$ Note (1964) 77 Harvard LR 741 at $p 751$.

${ }^{36}$ Fleming James, "Social Insurance And Tort Liability" (1952) 27 NYULR 537 at p 555: "He gambles a very small proportion of his premium on the chance of a windfall in excess of indemnity." Diplock LJ in Browning v War Office [1963] 1 QB 750 at p 769: "An accident insurance policy is a contract to pay a sum of money on a contingency; it is in the nature of a wager."

${ }^{37}$ M. A. Clarke, The Law Of Insurance Contracts (2nd ed 1994) para 4.2C, J. Birds, Modern Insurance Law (3rd ed 1993) chap 3. By contrast one writer asserts that the gamble justifies the retention of the collateral source rule because that rule "is designed to shield the insurance gamble from the tort system of resolving personal injury claims. In that way the gaming relationship between an insurer and its insured remains untainted." Flynn, "Private Medical Insurance And The Collateral Source Rule: A Good Bet?" (1990) Tol LR 39 at p 66.
} 
(e) Cumulation of payments is not allowed in other compensation contexts and in particular is prevented where a tort claim for property damage is involved

Even though a claimant has bought or earned entitlement to additional payments, they may be taken into account in a variety of contexts outside of tort to reduce, or even extinguish, the right to other compensation. For example, receipt of insurance monies affects entitlement to welfare benefits. It may also reduce the value of a claim under another insurance contract relating to the same loss. But the example most often used to attack the collateral source rule, even though payment has been made for the additional benefit, relates to the tort system itself. It concerns a tort claim for damage to property, rather than person. The plaintiff property owner is not allowed to retain, in addition to his damages, any insurance monies payable for the loss of his property. Instead the insurer is able to exercise subrogation rights and recoup from the damages the indemnity it has paid out under the terms of the policy. In practice the plaintiff does not bring the tort claim himself, but the insurer does so in the plaintiff's name. This is in sharp contrast to cases of personal injury where a plaintiff is allowed to keep all his damages in addition to any accident or life insurance monies. ${ }^{38}$

Can this different treatment of personal injury as opposed to property damage claims be justified? Insurance for property losses is said to have an indemnity basis whereas for accident and life assurance it does not. Indemnity means that a precise financial value can be placed on the loss and the policyholder is allowed to recover only to the limit of this loss. This means that if he has more than one policy, and is over-insured, there will be a pro-rata reduction in the amount payable by each policy so that no profit can be made. Similarly, if the policyholder is able to make a claim in tort as well as on his policy, he must use the proceeds to reimburse the insurer. There are two major policy reasons which support this principle of indemnity: first, there is a concern to minimise any incentive to fraud by preventing any profit being made from the destruction of property; and second, there is a reluctance to encourage gambling, the common law treating over-insurance with the suspicion that might be due a wagering contract.

${ }^{38}$ Bradburn v Great Western Railway Co (1874) LR 10 Exch. 1 
Unlike property insurance, both accident and life policies are considered nonindemnity insurances. ${ }^{39}$ The distinction is said to be based on the fact that precise financial values cannot be put on a person's life or on the disability which may result from an accident, ${ }^{40}$ and therefore there is no maximum amount at which the plaintiff could be said to be fully indemnified. It is then argued that he should be allowed multiple compensation. After all, what is a leg, arm or life worth? The sums must be artificial - there are no market values. If a plaintiff suffers paraplegia in a car crash, even though he recovers both damages in tort and accident insurance monies, it is difficult to assert that he has been overcompensated given that no precise market value can be placed upon his pain and suffering and loss of amenity. Nor can we suggest, as we could with property insurance, that the cumulation of payment provides an incentive for the injury to be caused, and is thus a temptation to fraud; self-mutilation in order to obtain insurance monies remains unknown, whereas arson to one's own property is relatively common.

But will this distinction between personal injury and property damage survive detailed scrutiny $?^{41}$ The Law Commission is not attracted to the argument that certain insurance payments are intended for non-pecuniary losses and can never be excessive because quantification is imprecise. ${ }^{42}$ Assessments in tort nowadays aim to achieve a measure of consistency according to a well recognised tariff of values

${ }^{39}$ Dalby $v$ India \& London Life Assurance Co (1854) 10 CB 365 (life), Theobald $v$ The Railway Passengers Assurance Co (1854) 10 Ex 45 at p 53 (personal accident).

${ }^{40}$ S. R. Derham, Subrogation In Insurance Law (1985) p 31 notes that in non-indemnity insurance the insured is entitled to recover upon proof of the occurrence of the event insured against, whereas under an indemnity policy proof of actual pecuniary loss is also required. See further $\mathrm{J}$. Birds op cit $\mathrm{p}$ 272, M. A. Clarke op cit para 31-3A.

${ }^{41}$ Kimball and Davis, "The Extension Of Insurance Subrogation" (1962) Michigan LR 841 argue that the distinction is untenable. Hasson, "Subrogation In Insurance Law - A Critical Evaluation" (1985) 5 OJLS 416 at p 418 similarly offers strong criticism: “... in the Alice-In-Wonderland world of insurance, life insurance contracts and accident insurance contracts were held not to be contracts of indemnity, despite the fact that it is clearly the intention of purchasers of these contracts to indemnify either their families (in the event of death) or, in the event of accident, to compensate themselves for their lost earnings. Why the loss of property should be treated differently from a loss of an arm, when both result in economic losses to the person who sustains them has never been explained." See also C. Mitchell, The Law Of Subrogation (1994) p 75. The Law Commission Consultation Paper Collateral Benefits (1997) paras 2.110 and 5.29 regard the distinction between indemnity and non-indemnity as puzzling and difficult. It suggests that there is as much reason to give subrogation rights in the one case as the other, and canvasses the possibility of removing all such rights so as to justify more easily the full deduction of benefits from damages.

${ }^{42}$ Consultation Paper Collateral Benefits (1997) para 4.60. 
for non-pecuniary loss. If an injured person were to receive monies on top of a full award for pain and suffering and loss of amenity he might be overcompensated. If the tort tariff itself is too low, the answer is for it to be reformed rather than permitting a random increase in the damages depending upon how much collateral benefit can also be claimed.

Another major difficulty with the argument that there is no overcompensation is that a substantial part of the damages awarded for personal injury is for pecuniary loss and this can be calculated fairly precisely. ${ }^{43}$ Actuarially, it is possible to measure the amount required by the plaintiff to be fully indemnified for his loss of wages or costs of care, and the court may have regard to such expert evidence when making its assessment. A formula is used based upon the yearly amount of the particular loss (the multiplicand), multiplied by the number of years during which that loss is expected to occur, less an allowance for the early receipt of payment (the multiplier, arrived at by applying the relevant discount rate). Although criticised, this formula is an attempt to calculate the financial costs of the accident as precisely as possible. This makes a claim for personal injury comparable with property damage, and thus undermines the argument that any collateral payments should be ignored.

In spite of these arguments, the legal effect of insurance payments upon damages remains unchanged. The law continues to apply the distinction between indemnity and non-indemnity insurance contracts in a mechanical manner treating the right to subrogation as arising by operation of law from the classification of the contract. ${ }^{44}$ As a result insurance payments are not deducted from damages for personal injury.

\section{(ii) Is Cumulation Justified If The Provider Of The Additional Payments Intended Them To Be Cumulative?}

If the donor intends to confer a benefit on the plaintiff, that intention will be frustrated if the benefit is taken into account in calculating damages because the

\footnotetext{
${ }^{43}$ According to the Pearson Commission op cit vol 2 table 107 only one third of the damages awarded in tort are for pecuniary losses. However, the percentage of pecuniary loss rises in proportion to the severity of the injury.

${ }^{44}$ See the forceful criticism in P. Cane, Tort Law And Economic Interests (2nd ed 1996) p 436.
} 
effect will be simply to transfer the value of the benefit to the tortfeasor. This not only appears unfair but might also deter the donor from offering help in the future. "The springs of private charity would be found to be largely, if not entirely, dried up." ${ }^{45}$ As Lord Reid suggested in Parry $v$ Cleaver: ${ }^{46}$

"It would be revolting to the ordinary man's sense of justice, and therefore contrary to public policy, that the sufferer should have his damages reduced so that he would gain nothing from the benevolence of his friends or relations or of the public at large, and that the only gainer would be the wrongdoer."

However, the argument is not without difficulty. Judges have acknowledged that 'the concept of 'the intent of the person conferring the benefit' [is] a somewhat elusive one." ${ }^{47}$ For example, it is often unclear what donors intend when making contributions to charity. The vast majority probably give no thought to the beneficiaries' ability to claim compensation from tort, although none intend to subsidise the tortfeasor. Many wish to provide immediate relief to those who have suffered rather than to supplement damages if they are eventually obtained. These charitable providers could be divided in their responses to the question: "Do you wish your contribution to go to the beneficiaries even if their losses have been fully compensated from other sources, whilst others suffering similar injuries receive no such assistance?" If the situation were properly explained to donors, they might well respond that instead of allowing the plaintiff to cumulate benefits, they would prefer that their insurance premiums be kept down.

This brings us to another aspect of the intention of the donor, but one which this time justifies the cumulation of benefit. If it is the intention of the donor only to provide immediate relief by making a loan to the plaintiff which must be repaid if any damages are obtained, receipt of the immediate financial assistance ought not to be taken into account later to reduce the award of compensation. This is because there will be no overcompensation of the plaintiff; the loan must be repaid. The rule has

\footnotetext{
${ }^{45}$ Andrews LCJ in Redpath v Belfast And County Down Railway [1947] NI 167 at p 170. Similarly according to the Scottish Law Commission deduction "might discourage philanthropy and, in effect, divert these payments from their intended object." Damages For Personal Injuries: Report On (1) Admissibility Of Claims For Services; (2) Admissible Deductions (1978) Report No 51, para 58.

${ }^{47}$ Lord Bridge in Hodgson v Trapp [1989] 1 AC 807 at p 822.
} 
been supported by law reform bodies. ${ }^{48}$ It is an important one because it is very common for today's contracts of employment to contain a clause giving the employer the right to recoup sickness payments if the claim for damages proves successful. ${ }^{49}$ It is open to employers to insert similar provisions in their pension arrangements as well as any permanent health and redundancy protection they arrange for their employees. However, as yet such clauses are rarely inserted into the relevant agreements. This is because of a failure to plan for the possibility of a tort claim rather than any inherent problem with the concept of inserting such a clause.

\section{(iii) Is Cumulation Justified If Damages Alone Are Inadequate Compensation?}

The case for the plaintiff keeping both damages and collateral benefits is stronger if damages do not fully indemnify against loss. In its empirical survey the Law Commission found that two in five recipients of damages thought that their monies were insufficient, largely because they believed they were under-compensated for loss of earnings. ${ }^{50}$ In order to make up for the shortfall they had cut back on their ordinary living expenses. Some had been forced to take out loans or had dipped into their savings.

There are several reasons why the damages may prove insufficient:-

$\rho$ Any reduction in the award because of the plaintiff's contributory negligence may mean that the damages will be insufficient to meet the plaintiff's future

${ }^{48}$ Pearson Commission op cit para 504, Scottish Law Commission op cit para 62. The Law Commission Consultation Paper Collateral Benefits (1997) para 4.80 suggests that a wider principle of deduction might be adopted, but it continues to make an exception "where the provider of the collateral benefit has a right (by contract or by operation of law) to recover the benefit ...."

${ }^{49}$ For example, the British Rail sick pay scheme used to contain the following clause: "In respect of absence due to an accident or injury occurring either on or off duty, sick pay under these arrangements will be paid as a loan which will be repayable to British Rail in the event of the member of the staff involved in such occurrence recovering damages from a third party or British Rail, or compensation from the Criminal Injuries Compensation board or any other body set up for a similar purpose."

${ }^{50}$ Law Commission Report No 225 (1994) Personal Injury Compensation: How Much Is Enough? chap 11 and table 1102. Under-compensation also occurred because of losses and expenses not anticipated at the time of the settlement. 
needs. It has been estimated that the defence reduces damages in about a quarter of all settlements, but there are no precise figures. ${ }^{51}$

$\rho$ The way in which the courts assess damages can lead to under-compensation. Judges have refused to apply actuarial principles in order to assess future loss. As a result, they have been accused of making excessive and unjustified discounts from what ought to be awarded. For example, they may reduce an award to reflect uncertainty about what will happen to the plaintiff in the future including the risks of premature death or redundancy. But in making allowance for these "vicissitudes of life," or "contingencies," judges have penalised plaintiffs more than an actuarial analysis would allow. Similarly, the discount rate used to allow for the accelerated receipt of damages has been said to be too high. ${ }^{52}$

$\rho$ In cases which are settled the risks and the trauma associated with proceeding to trial are avoided, and the compensation is received sooner than would otherwise be the case. These benefits are inevitably reflected by a discount from the damages a court would award. ${ }^{53}$

$\rho$ The costs of bringing the action are borne in part by the plaintiff even though the claim is successful. A legal aid contribution may be required, or payment to the lawyer in excess of that obtained as party and party costs from the defendant. In the USA the use of the contingent fee in order to fund the

${ }^{51}$ D. Harris et al, Compensation And Support For Illness And Injury (1984) p 91. It is very difficult to analyse the effect of the defence upon the level of settlement because the parties do not agree whether and to what extent contributory negligence is a factor in the final settlement. A more recent study by the Law Commission found at least 12 per cent of recipients of damages awards considered that the defence had been relevant in reducing their payments. See How Much Is Enough? op cit table 407. In a survey confined to serious injuries - worth at least $£ 150,000$ or more although there were clear indications that the defence was used in only nine per cent of cases, it featured in negotiations in other cases without its effect being clear. P. Cornes, Coping With Catastrophic Injury (1993) p 22.

${ }^{52}$ For details see Law Commission Report No 224 (1994) Structured Settlements And Interim And Provisional Damages Part II and the Consultation Paper No 125 (1992) paras 2.91 - 2.18. The discount rate has recently been the subject of litigation, and awaits determination by the House of Lords. See Wells v Wells [1997] PIQR Q1.

${ }^{53}$ Harper and James op cit $\mathrm{p} 1354$ state: “... the double recovery result in the accident insurance cases is hard indeed to justify on principle though perhaps it has done little harm in practice for, as practical claims men know, the beneficiary of an accident policy is usually willing to settle his tort claim for less than he otherwise would." 
litigation has often been relied upon to justify the collateral source rule. ${ }^{54}$ The lawyer commonly takes up to a third of the damages awarded. However, by contrast in Britain the plaintiff is required to make only a limited contribution, and the justification for cumulating the collateral benefits has much less force.

$\rho$ It has already been suggested that money cannot adequately compensate for non-pecuniary losses. Payment for pain and suffering is not an indemnity, and it is possible to argue that any sum is insufficient and cumulation should therefore be allowed. However, against this it must be recognised that a court regards the amount it awards for non-pecuniary loss as a sufficient sum. Within the tort system it would not allow a plaintiff to recover more. For example, there is no increase in the amount awarded for non-pecuniary loss just because more than one tortfeasor is sued. Why then must additional compensation from a collateral source be ignored?

Some of the reasons given above for damages being inadequate cannot alone justify collateral monies being left out of account. A more rational compensation system would require that more accurate assessment of damages be made rather than allowing its deficiencies to be corrected in a haphazard way by the addition of collateral monies. It is a matter of luck whether the plaintiff has recourse to such additional payments, and they bear no relationship to the extent that there would otherwise be undercompensation. As Luntz states:

"The remedy for underestimation of the loss is to make the estimating process more scientific, not to adopt a swings and roundabouts approach which offsets a loss suffered by many plaintiffs with fortuitous gains to some. ${ }^{.55}$

The Law Commission agree: if damages do not fully compensate that problem must be addressed directly. ${ }^{56}$

\footnotetext{
${ }^{54}$ Goldsmith, "A Survey Of The Collateral Source Rule: The Effects Of Tort Reform And Impact On Multistate Litigation" (1988) 53 J Air Law And Commerce 799 at p 802, and the American Law Institute, Enterprise Responsibility For Personal Injury Vol 2 (1991) p 164. The Institute suggested that the plaintiff should be able to recover legal costs as a separate head of damage, thus removing the justification for the cumulation of benefits.

${ }^{55}$ H. Luntz, Assessment Of Damages For Personal Injury And Death (3rd ed 1990) para 8.1.10.

${ }^{56}$ Consultation Paper Collateral Benefits (1997) para 4.10.
} 
(iv) Is Cumulation Justified If Damages Are Awarded For Purposes Different From The Additional Payments?

If the purpose of the additional payment is to replace something with a clear financial value, and that purpose would be exactly duplicated by part of the damages award, there is less reason for the award to ignore the additional payment. It appears wasteful to compensate for a particular need that has already been satisfied. However, if the payment is made for some purpose different from that of the damages award then it is more likely to be left out of account.

This argument is used to justify offsetting types of benefit only against their corresponding part of the damages award. For example, the Pearson Commission proposed that damages be divided into three elements: compensation for lost income, for expenses, and for non-pecuniary loss. ${ }^{57}$ It then classified a number of social security benefits as falling within one of these three categories and proposed that they could only be offset against the relevant part of the damages award. This would mean that benefits for sickness and invalidity could only be taken into account to reduce the damages for the loss of income caused by the accident; if these damages were reduced because of contributory negligence so that the amount received for lost income was less than the benefits received, the surplus benefit could not be set off against the non-pecuniary part of the damages award.

The argument also helps to explain the result in the leading case of Parry $v$ Cleaver. ${ }^{58}$ It was agreed that the sick pay was to be deducted from the damages for lost earnings, but the disablement pension was not. This was because the pension would have been paid even if the plaintiff had been able to obtain other work and so earn during the relevant period, whereas there would then have been no entitlement to the sick pay. By contrast, the dissenting judges considered the pension to be a form of deferred pay, analogous to wages, and therefore deductible. The Law

\footnotetext{
${ }^{57}$ Op cit chap 13.

58 [1970] AC 1.
} 
Commission is very critical of the majority view and suggests that the attempt to characterise the payments as different in kind is unsustainable. ${ }^{59}$

In the USA the suggestion that the collateral source rule be abolished and that all additional payments be brought into account has often been subject to the exception that the proceeds of a life insurance policy are to be ignored. This is because such policies are not only purchased to provide financial cover in the event of death, but also as a form of investment and saving. The different purpose justifies treatment which is distinct from accident, health or disability insurance. ${ }^{60}$

The strength of the argument depends upon the purposes of both the damages award and the collateral benefit being clear, and this may not be the case. For example, in settlements of tort claims, as opposed to the cases which are determined by a court, there is no agreed division of the compensation into pecuniary and non-pecuniary loss. Using these categories it can also be difficult to classify certain payments. To what extent is a fixed amount under a private insurance policy a payment for the financial effects of injury as opposed to the loss of amenity that may result? Subdividing the compensation may not only be complex but also unrealistic because it may not correspond to how the recipient perceives his damages to have been computed. Finally, the more precise the set off, the less scope there is to avoid cumulation of damages, with the result that the gap is widened between those who obtain damages and those who are left to rely upon social security benefits. ${ }^{61}$

${ }^{59}$ Consultation Paper Collateral Benefits (1997) paras 2.104 - 2.109, similarly see A. Ogus, The Law Of Damages (1973) p 227.

${ }^{60} \mathrm{O}$ 'Connell argues that term insurance cannot be justified on the ground of investment and therefore ought to be brought into account in "A Proposal To Abolish Contributory And Comparative Fault, With Compensatory Savings By Also Abolishing The Collateral Source Rule" (1979) 3 Univ Illinois Law Forum 591.

${ }^{61}$ Atiyah, "What Now?" in Accident Compensation After Pearson (1979) ed D. Allen et al p 227 at p 248. 


\section{(v) Is Cumulation Justified If The Expense Of Avoiding It Is High?}

It may be administratively too burdensome and too costly to prevent cumulation by, for example, arranging for the collateral sources to be reimbursed. This is considered below in relation to the policy of recoupment.

\section{(vi) Is Cumulation Justified If It Prevents The Tortfeasor Receiving The Benefit?}

The price required to avoid cumulation may prove unacceptable if it involves subsidising the tortfeasor. There may be moral and economic reasons why the defendant's burden should not be reduced. These are considered below in relation to the policy of reduction.

\section{REVIEW OF THE POLICY OF RECOUPMENT}

On the surface recoupment seems the most attractive of the solutions to the problems posed by the overlap of benefits: it prevents the over-compensation of the plaintiff, as discussed above in relation to the policy of cumulation; and it avoids subsidising the defendant, discussed below in relation to the policy of reduction. Reimbursing the collateral source is especially attractive to those concerned about the wasteful aspects of the tort system for, in theory, money could be saved and reallocated to those who are seriously disabled but unable to mount a tort claim. Damages are obtained only by a small minority of accident victims and these, in turn, constitute but a fraction of those disabled from all causes. If money could be transferred from the "elite" group ${ }^{62}$ to those less fortunate there would be a more equitable distribution of the finite resources available. The difficulty with this lies in the presumption that recipients of tort damages are indeed over-compensated, and that any savings made could be reallocated easily to equitably compensate others. In practice the savings are likely only to boost insurers' profits, or lower the premiums they charge. If a collateral source is refunded, the monies are rarely earmarked for reallocation for similar purposes. Instead the savings are absorbed into the general pool. This also happens, for example, where the state reduces

${ }^{62}$ The Disablement Income Group opposed the Pearson Commission proposals to improve the tort system because they would make "an elite group even more elite." The Times, July 251978. 
expenditure by "targeting" benefits for disabled people more precisely. The savings made are not used to improve allied provision but disappear instead into the general coffers of the Treasury. In short, although in theory recoupment appears to offer the possibility of an equitable redistribution of resources, in practice it rarely occurs. Apart from difficulties with this wider policy goal, there are other problems associated with recoupment. In particular, it may be administratively difficult to bring a third party into the proceedings, and it could prove costly to do so compared to the amount of money recouped.

\section{The Expense And Administrative Burden Of Recoupment}

A common criticism of recoupment is that it could prove expensive when compared to the value of the benefit clawed back. It requires the collateral payments or services to be valued, and arrangements to be made for the source to be reimbursed. This may mean that the source is joined as a third party to the proceedings brought by the plaintiff. Alternatively, the source may have to bring proceedings itself for the support it has given and make a claim either directly in its own name or on behalf of the accident victim. Depending on the circumstance, the collateral source may have to bear the cost of the litigation. This could be considerable, especially if it is necessary to establish that the injury was caused by another's wrongdoing. The uncertainties and risks attached to the fault principle are well known and may make the game of recoupment not worth the candle, one commentator going as far saying it is "economically ludicrous." ${ }^{63}$ More moderately, Kimball and Davis conclude, as most academics have, that "there may be many problems to which abrogation of subrogation would be a desirable solution ...."

It is largely because of the potential costs involved that insurers make little use of their right of subrogation. Although empirical evidence is sparse, one study of insurance practice in the USA suggests that the cost of subrogation in less serious accidents could amount to half of the sum claimed. ${ }^{65}$ As a result insurers often allow tortfeasors to escape without paying for the damage they cause because it is too

\footnotetext{
${ }^{63}$ Cooper, "A Collateral Benefits Principle" (1971) 49 Can B Rev 501 at p 531.

${ }^{64} \mathrm{Op}$ cit at $\mathrm{p}$ 871. See further Hasson op cit.

${ }^{65}$ R. C. Horn, Subrogation In Insurance Theory And Practice (1964).
} 
expensive or difficult to do otherwise. Both fire and household insurances illustrate the limited use of recoupment. Recoveries in respect of such policies are less than one per cent of the losses paid. ${ }^{66}$ Although more use is made of subrogation where property damage to motor vehicles is involved, ${ }^{67}$ insurers again have found the potential costs prohibitive. As a result, insurers have entered into "knock for knock" agreements with other insurers. Under such agreements, even though an insurer has paid for the damage done to a vehicle owned by one of its comprehensively insured policyholders, it is obliged not to pursue an action against the driver who caused that damage provided that he was insured by the other party to the agreement. The premise is that whatever the insurer loses in this particular case he will regain in the next, and the costs of litigating will have been saved. These agreements between motor insurers were first made as long ago as the beginning of this century and have been widely used. They have also been extended to other forms of insurance ${ }^{68}$ and are widespread in France and Germany. ${ }^{69}$ Although they have declined in importance in the 1990's, this does not mean that insurers have become more enthusiastic about subrogation, but only that they no longer subscribe to the premise that each carries a proportionate share of the bad risks. ${ }^{70}$

${ }^{66}$ Derham op cit p 153 citing Horn op cit 173.

${ }^{67}$ Meyer found that subrogation in motor claims for property damage amounted to 8 per cent of the losses, and in marine insurance it was as high as 14 per cent. However, these were the only two areas where subrogation played any significant role. See "Subrogation Rights And Recoveries Arising Out Of First Party Contracts" (1973) 9 The Forum 83.

${ }^{68}$ Lewis, "Insurers' Agreements Not To Enforce Strict Legal Rights: Bargaining With Government And In The Shadow Of The Law" (1985) 48 MLR 275.

${ }^{69}$ In these countries providers of collateral benefits are given extensive subrogation rights. However, they enforce these largely through bulk recovery agreements whereby liability insurers agree in advance to pay a percentage of all claims under a certain amount from particular collateral benefit providers. This avoids litigating individual cases and makes subrogation administratively workable and financially acceptable. See W. Pfenningstorf and D. Gifford, A Comparative Study Of Liability Law And Compensation In Ten Countries And The USA (1991) p 134. The Law Commission recognises that the conclusion of bulk agreements in this country would be complicated and costly and lead to a myriad of arrangements between individual employers, first party insurers, and pension funds on the one hand, and liability insurers on the other. See the Consultation Paper Collateral Benefits (1997) para 5.19.

${ }^{70}$ M. A. Clarke op cit n 37 para 31-7B1. 
With regard to statutory rights to seek reimbursement, Cane notes another example of the potentially high cost of collecting the payment. ${ }^{71}$ At present the NHS is allowed to recoup from insurers only some of the cost of its treatment of the victims of motor vehicle accidents. The cost of collecting the relatively small sum involved is about a quarter of the value of the proceeds. It would be far more efficient instead to increase the general level of taxation of insurers, although of course this is imprecise and penalises those who insure the safer risks.

In favour of recoupment it must be emphasised that the greater the amount of benefit available for clawback, the greater the likelihood that the costs involved will prove worthwhile. In addition, measures can be taken to improve its cost effectiveness. These include imposing a threshold level of recovery below which recoupment is not to operate. However, in assessing the economic efficiency of recoupment it is not sufficient to look only at the costs incurred by the agency seeking reimbursement. Subrogation, for example, has been heavily criticised as encouraging overlapping policies - both loss and liability insurances may be taken out for the same risks in respect of the same damage. ${ }^{72}$ This benefits only insurers. In addition, if the plaintiff and the defendant are engaged in the same activity, the reallocation of the loss as a result of subrogation may have no effect upon the group that ultimately shoulders the burden. For example, after a car accident an insurer might try to recoup the compensation it has paid out for vehicle damage, but this may serve only to redistribute the burden from one group of drivers to another. Motorists overall will bear the loss. The cost of shifting the exact incidence of payment in such a case is wasteful.

\section{The Mechanism For Arranging Recoupment}

Recoupment depends not only upon the collateral source having a financial incentive to take action, but also upon the opportunities provided by the legal system

${ }^{71}$ Op cit $\mathrm{p} 342$, citing the Report of the NHS Scrutiny Programme, The Collection Of Fees By Health Authorities Under The Road Traffic Act 1972 (DHSS 1985).

${ }^{72}$ Hasson op cit p 425 illustrates this by referring to the commercial situation where both landlord and tenant may carry first party insurance for the leased property which is also covered in the third party liability policies protecting those who supply the tenant with goods or carry out repairs on the property. Overlaps arise because potential plaintiffs insure against the possibility of damage irrespective of whether they may be able to pursue a tort action to obtain compensation, whilst defendants also insure the same loss against their tortious liability. 
to bring the relevant proceedings. ${ }^{73}$ To obtain reimbursement it may be necessary for the collateral source to make a claim against the tortfeasor or even against the plaintiff himself:

Against the tortfeasor, the source may rely upon a right of subrogation and bring the action in the plaintiff's name. Alternatively, there may be a statutory right to recoup the monies, as where the state is able to obtain reimbursement of its social security payments. In the past there have also been attempts to bring an action in quasi-contract for money paid by the collateral source to the use of the defendant. ${ }^{74}$ recipients of damages are almost unknown, there are several theoretical bases upon which they may be founded. First, reliance may be placed upon a condition imposed by the court when awarding damages that part of the money be used to repay the provider of the additional benefit. ${ }^{75}$ Some cases have specifically held that the plaintiff should hold part of the damages on trust, ${ }^{76}$ although there are considerable difficulties in the use of this concept. ${ }^{77}$ It is also theoretically possible for the collateral source to rely upon the concept of unjust enrichment in the law of restitution. ${ }^{78}$

${ }^{73}$ See Law Commission Consultation Paper Collateral Benefits (1997) paras 2.84 - 2.90.

${ }^{74}$ The claim failed in Metropolitan Police District Receiver v Croydon Corporation [1957] 2 QB 154. The case is criticised by the Law Commission who canvass the possibility of overturning it and creating a new statutory right of recoupment for providers of collateral benefits. See the Consultation Paper Collateral Benefits (1997) paras 5.4 et seq. The action per quod sevitium amisit was abolished by the Administration Of Justice Act 1982. See further McGregor op cit p 639, and Cooper op cit $\mathrm{p} 523$.

${ }^{75}$ Although this device seems not to be employed today, it was used in Dennis V L.P.T.B. [1948] 1 All ER 779 and contemplated by Goddard LJ in Allen v Waters \& Co [1935] 1 KB 200 at p 215. The Law Commission doubted whether the court has power to impose conditions on the award of damages in its Report On Personal Injury Litigation - Assessment Of Damages (1973) Report No 56 para 141.

${ }^{76}$ Hunt $v$ Severs [1994] 2 AC 350.

${ }^{77}$ Matthews and Lunney, “A Tortfeasor's Lot Is Not A Happy One” (1995) 58 MLR 395.

${ }^{78}$ A. Burrows, The Law Of Restitution (1993) p 218 and the Law Commission Consultation Paper Collateral Benefits (1997) para 5..22. For an application of the principle see the Law Commission Consultation Paper No 144 Damages For Personal Injury: Medical, Nursing And Other Expenses (1996) at para 3.21: "To grant the NHS a right in tort to recover from the tortfeasor damages to cover its care costs caused by the tort, may be said to be contrary to the normal negligence principles that pure economic loss is irrecoverable. However, the restitutionary principle of unjust enrichment arguably supports such a right for the NHS." 
Indeed this has been seen as the main basis for subrogation itself. ${ }^{79}$ Finally, and most important in relation to sick pay schemes, the provider of the benefit may rely upon a contractual right to repayment as where monies are advanced on the condition that they will be returned in the event of the victim's claim for damages proving successful.

However, in the absence of appropriate legal concepts recoupment will not be possible. There may then be no mechanism for the court to arrange for recoupment no matter how much it may think it a desirable policy to pursue.

\section{REVIEW OF THE POLICY OF REDUCTION}

Although this policy reduces damages by the amount of benefit received, it does not require the collateral source to be reimbursed. Therefore, of the three policies identified in this chapter, reduction is the most favourable to defendants. They not only pay less money to plaintiffs but they also avoid paying anything to the collateral sources. On the surface this solution seems the least attractive of the three. It appears to subsidise the wrongdoer at the expense of the Good Samaritan and thus offends our sense of morality. Reduction also undermines the deterrent aspect of the law of tort. It limits the financial penalty imposed for careless behaviour and thus lessens the incentive to minimise the risk of causing injury. In summary, the objection is that it reduces the extent to which the tortfeasor bears responsibility for his actions. However, the policy of reduction can be defended on the basis of its simplicity. In particular, it avoids the transfer costs associated with recoupment and the wasteful duplication of payment which may result from cumulation.

Although generally in tort law the aim of awarding just compensation has taken precedence over that of deterrence ${ }^{80}$ there are a few collateral benefit cases where courts have specifically referred to their desire to punish the defendant as a wrongdoer. He is made to pay in full and is said not to deserve to benefit from the generosity of the third party: ${ }^{81}$

\footnotetext{
${ }^{79}$ C. Mitchell, The Law Of Subrogation (1994) p 9 et seq.

${ }^{80}$ Williams, "The Aims Of The Law Of Tort" (1951) 4 Current Legal Problems 137.

${ }^{81}$ Yates $v$ Whyte (1838) 4 Bing NC 272 at p 283.
} 
"... in these cases the courts measure 'compensation' by the total amount of harm done, even though some of it has been repaired by the collateral source, not by what it would take to make the plaintiff whole. It is 'compensation' in a purely Pickwickian sense that only half conceals an emphasis upon what the defendant should pay rather than on what the plaintiff should get." ${ }^{.82}$

The result of this change of emphasis is that the policy of reduction is abandoned in favour of cumulation or recoupment.

However, this desire to ensure that the defendant gets his just deserts by preventing him from transferring responsibility for payment to another can be misplaced, especially given the extent to which individual responsibility for wrongdoing has already been removed from the tort system. The arguments against reduction of damages lose much of their force if we move away from injuries which have been caused deliberately and consider instead those caused by negligence. In very few of these cases are tortfeasors required to pay damages personally. There are many reasons for doubting whether the law can act effectively as a deterrent in such cases. ${ }^{83}$ In particular, it is hard to see how the policy of reduction could have any effect on the extent that undue risks are taken. In summary, these reasons are as follows:

$\rho \quad$ Fear of civil liability plays little or no part in regulating risk taking behaviour. The deterrent aspect is removed because of the protection afforded by liability insurance. The great majority of defendants found liable in tort do not pay damages; their insurers do so. ${ }^{84}$ The defendant may suffer little, if at all, financially: even future insurance premiums are likely to remain unaffected. ${ }^{85}$ People take care to avoid causing injury not because of fear of civil liability, but because they wish to reduce the risk of injuring

\footnotetext{
${ }^{82}$ F. V. Harper and F. James, Law Of Torts Vol 2 (1956) p 1344.
}

${ }^{83}$ See further P. Cane op cit n 2 pp 363-369. The arguments based on the wider economic perspective of market deterrence are summarised at pp 374-394 and are not repeated here.

${ }^{84}$ The Pearson Commission estimated that insurers dealt with 88 per cent of tort claims and paid 94 per cent of the total damages. Op cit vol 2 para 509.

${ }^{85}$ Protected no-claims bonuses are widely available for motor insurance, and most employers are rated not according to their actual experience of accidents, but only according to the general classification of the type of work they do. Atiyah, "Accident Prevention And Variable Premium Rates For Work Connected Accidents" (1975) 4 Ind LJ 89. 
themselves, their property or other people. Self preservation and a natural concern for the safety of others are the important motivating factors. Finally, it is clear that the possibility of being found guilty of a crime is far more effective as a specific deterrent than the imposition of civil liability. The vast majority of claims for compensation from tort do not involve intentional wrongdoing where injury is inflicted as a result of obviously reprehensible conduct. Instead most claims result from accidents which are the product of a moment's inattention or slip. Many of these errors in fact are ones we all make frequently, but fortunately they result in no injury and no tort action because, for example, there was no oncoming car at the time. Other errors arise where people are not conscious that they are involved in a risky activity. As a result, it is difficult to characterise the wrongdoing as morally bad. ${ }^{86}$ The possibility of influencing the natural behaviour in which such mistakes arise is very limited so that it is difficult to reduce the incidence of injury. Tort imposes liability upon the basis of rules which are vague and provide little guidance in advance as to the action that should be taken. For example, tort's simple exhortation to take care and drive at a reasonable speed is of little value to the learner driver. By contrast, the criminal law provides a much clearer indication of what is required. Apart from this uncertainty of what standard of care the law demands in a given situation, there is also uncertainty about the ability of courts to adjudicate upon accidents long after they happened. At one extreme it has even been suggested that the forensic process is so flawed that the parties might as well toss a coin instead to establish liability. ${ }^{87}$ Apart from difficulties in assembling and presenting evidence of wrongdoing, there is also concern about how judges might interpret it for they are naturally inclined to make some provision for the tragic victims of accidents coming before them. Legal practitioners are only too aware that liability is

\footnotetext{
${ }^{86}$ Diplock LJ in Browning v War Office [1963] 1 QB 750 at p 764 deliberately used the word defendant 'rather than applying ... so emotive a label as 'wrongdoer' or even 'tortfeasor,' for the emotions with which these latter expressions are charged tend ... to obscure ... the realities of the situation in the modern world."

${ }^{87}$ D. W. Elliott and H. Street, Road Accidents (1968) p 243.
} 
sometimes imposed out of natural sympathy for the victim rather than because of the wrongdoing of the defendant. Again this suggests that the policy of reduction could be supported in certain cases, and may be especially appropriate where the defendant, although found liable, in fact may have done little wrong. The extent of the damages the defendant is required to pay bears little relationship to the amount of his wrongdoing. There is no norm of damages which has been set for particular acts of negligence. ${ }^{88}$ If damage does not result nothing is to be paid. If loss is caused the compensation will depend not upon the degree of fault, but upon the extent of injury, including the particular earning capacity of the plaintiff. That is, the policy of reduction could be applied without necessarily reducing the deterrent below that appropriate for the particular act of negligence.

As a result of these and other attacks upon the deterrent effect of tort law, the Law Commission conclude that

"... as tort law in general has difficulty in deterring wrongdoing, the deterrent effect of damages being increased by the amount of the collateral benefits must surely be negligible. Accordingly we do not think that an approach to collateral benefits which diverges from that which the compensation aim dictates can be justified on the basis of the deterrence it achieves." 89

These attacks on tort law as a deterrent may also be used to undermine the moral basis for imposing full liability. Insofar as that moral basis is said to rest upon the natural feelings of those injured that the wrongdoer should be made to pay in full, it must be noted that many plaintiffs do not harbour such feelings. Those injured by members of their family or by workmates may well consider that they should have a right to compensation, but not that the wrongdoer should be made to pay personally. ${ }^{90}$ Recoupment in such circumstances might prove to be an unwelcome

\footnotetext{
${ }^{88}$ See Diplock LJ's forceful criticism to this effect in Browning v War Office [1963] 1 QB 750 at p 764.

${ }^{89}$ Consultation Paper Collateral Benefits (1997) para 4.17.

90 Lloyd-Bostock, "Commonsense Morality And Accident Compensation" in D. P. Farrington et al, Psychology, Law And Legal Process (1979), and Harris, op cit chap 4.
} 
intrusion, and for this reason subrogation against individual employees has been abandoned by employers liability insurers. ${ }^{91}$

Apart from attacking tort law as a deterrent and as inadequately reflecting certain moral precepts, the case against the policy of reduction is further weakened by emphasing the costs involved in the alternatives. We have already seen that, of all the solutions to the problem of overlapping compensation, reduction may be the most economically efficient. This is because it avoids not only the high costs which may accompany recoupment as described above, but also the waste involved in cumulation.

\section{CONCLUSION}

This article has explored policies relating to an area of law which is central to the future development of compensation for personal injury. The inter-relationship of schemes is crucial in understanding the overall provision made for those incapacitated and disabled in society. However, until recently comparatively little attention had been paid to collateral benefits in spite of the regular stream of litigation on the subject. The Law Commission review has now brought the area into sharper focus.

The Consultation Paper considers a wide range of options for reform. It favours, to a greater or lesser degree, increasing the extent that benefits are deducted. Its most comprehensive option is to deduct all collateral benefit from damages. ${ }^{92}$ It generally favours some form of recoupment. Although this article has emphasised in a more abstract way the value of this approach, it has also acknowledged the qualifications that must be made to it. In particular, the extent of overcompensation that results from cumulation can easily be exaggerated, and it may not occur at all in many cases. As for the policy of reduction, many of the objections to subsidising the tortfeasor lose their force when it is realised that very few defendants pay damages

\footnotetext{
91 Lister v Romford lce Co [1957] AC 555 has been subverted by a private agreement between insurers and employers organisations that subrogation will not be used. Lewis op cit at $p 281$.

92 Consultation Paper Collateral Benefits (1997) para 4.80. This is subject to two provisos: if a benefit is paid for a particular loss it should be deducted only from the corresponding part of the damages award; and there should be no deduction if the provider of the benefit has a right to recover the value of the benefit from the plaintiff.
} 
personally. The most desirable solution in any given case inevitably depends upon the particular facts. No matter how attractive on the surface recoupment seems to be in preventing both the overcompensation of the plaintiff and the subsidising of the defendant, it makes no sense to pursue that solution irrespective of the cost involved in reallocating the losses. Particular attention must be given to whether subrogation rights are sufficiently cost effective to be retained.

The attraction of moving away from the policy of cumulation is that it avoids one of the more wasteful aspects of the present tort system. If the monies saved could be more equitably allocated to a wider group of disabled people suffering the same injuries then the reform would have many supporters. However, achieving such a transfer of resources is somewhat easier said than done. The article therefore prompts the following final question: should a welfarist reviewing the tort system support cuts in damages now in the hope of the more equitable reallocation of resources at some later date, or should a defence be mounted of the existing level of support given to the fortunate few who succeed in their common law claim? The dilemma, faced by many such as the present author in giving assistance and evidence to the Law Commission, is an acute one.

WORDS 10,159 